\title{
The potential of agricultural headwater streams to retain soluble reactive phosphorus
}

\author{
Gabriele Weigelhofer
}

Received: 27 October 2015/Revised: 23 March 2016/ Accepted: 18 April 2016

(C) The Author(s) 2016. This article is published with open access at Springerlink.com

\begin{abstract}
The study focuses on the capacity of agricultural headwater streams to retain soluble reactive phosphorus (SRP). In-stream phosphorus uptake was determined via short-term SRP additions in 14 reaches differing in channel morphology and riparian vegetation. In addition, zero equilibrium phosphorus concentrations $\left(\mathrm{EPC}_{0}\right)$ were estimated for 8 reaches based on adsorption experiments. Average SRP uptake lengths amounted to $3.8 \mathrm{~km}$ in channelized sections, $1.9 \mathrm{~km}$ in forested sections, and $0.5 \mathrm{~km}$ in open meanders. Mass transfer coefficients were highest in open meanders $\left(0.1 \mathrm{~cm} \mathrm{~min}^{-1}\right)$, followed by forested $\left(0.05 \mathrm{~cm} \mathrm{~min}^{-1}\right)$ and channelized sections $\left(0.04 \mathrm{~cm} \mathrm{~min}^{-1}\right)$. $\mathrm{EPC}_{0}$ ranged from 20 to $1,600 \mu \mathrm{g}$ SRP $1^{-1}$ and correlated positively with inorganic $\mathrm{P}$ and reductant-soluble $\mathrm{P}$
\end{abstract}

Electronic supplementary material The online version of this article (doi:10.1007/s10750-016-2789-4) contains supplementary material, which is available to authorized users.

Guest editors: Mary Kelly-Quinn, Jeremy Biggs \& Stefanie von Fumetti / The Importance of Small Water Bodies: Insights from Research

G. Weigelhofer $(\bowtie)$

WasserCluster Lunz, Dr Carl Kupelwieser Promenade 5, 3293 Lunz/See, Austria

e-mail: gabriele.weigelhofer@wcl.ac.at

G. Weigelhofer

Institute of Hydrobiology and Aquatic Ecosystem Management, University of Natural Resources and Life

Sciences, Max Emanuelstr. 17, 1180 Vienna, Austria concentrations of the sediments. In 50\% of the reaches, phosphorus was released from the sediments at initial water concentrations of up to $500 \mu \mathrm{g} \mathrm{SRP} 1^{-1}$, indicating a high release potential. Although $\mathrm{EPC}_{0}$ did not correlate with in-stream SRP uptake, sediments probably play a significant role for the $\mathrm{P}$ retention in agricultural headwater streams as they supply the benthic community with phosphorus from the subsurface. Thus, it is crucial that sediment-water interactions are considered in the restoration and management of agricultural headwater streams.

Keywords Agriculture $\cdot$ Headwater streams ·

Sediments · Phosphorus uptake $\cdot$ Phosphorus release · Equilibrium phosphorus concentrations

\section{Introduction}

Headwater streams have an important function in the retention and processing of dissolved and particulate organic matter and nutrients from the terrestrial surroundings (Alexander et al., 2007; Kristensen \& Globevnik, 2014). Comprising about two-third of the total river length in European countries and the U.S. (Kavanagh \& Harrison, 2014; Kristensen \& Globevnik, 2014), small headwater streams are important links between the catchment and downstream reaches (Reddy et al., 1999; Dodds \& Oakes, 2008). Due to their usually diverse channel morphology and their 
low discharge, pristine headwater streams can retain and process large amounts of nutrients and organic carbon from the catchment, thereby controlling matter transport into the remaining river system (Hall et al., 2002; Alexander et al., 2007; Hall et al., 2013). This retention function has become increasingly important in the face of the expansion and intensification of agriculture during the twentieth century (Gordon et al., 2008; Withers \& Jarvie, 2008). Today, agricultural land use is the major source of nutrients in Europe, contributing up to $80 \%$ of the nitrogen and up to $40 \%$ of the phosphorus inputs into European river systems (Oenema et al., 2005; Bouraoui \& Grizzetti, 2011). Excessive loads of dissolved phosphorus are problematic for freshwater systems as phosphorus is often the limiting nutrient and may lead to the eutrophication of both lentic and lotic water bodies (Tank \& Dodds, 2003; Stutter \& Lumsdon, 2008; Withers \& Jarvie, 2008; Elsaholi et al. 2011). Efficient and adequate phosphorus retention within headwater reaches is, thus, a prerequisite for the protection of European streams and rivers.

However, agricultural land use impairs the integrity and retention function of stream ecosystems in multiple ways, affecting not only the quantity and quality of water flows, but also the character of the stream channel and its riparian zone (Hancock, 2002; Gordon et al., 2008; Withers \& Jarvie, 2008; Weigelhofer et al., 2013). Besides, small headwater streams are specifically susceptible to even subtle human impacts (Kristensen \& Globevnik, 2014). Due to their low discharge, headwater streams only have limited capacities to compensate increased nutrient or soil inputs from the terrestrial surroundings via dilution or sediment transport. Consequently, even minor local inputs of nutrients may exceed the nutrient demand of the benthic community and lead to the saturation of the systems, a phenomenon commonly observed in agricultural headwater streams (Merseburger et al., 2005; Bernot et al., 2006; Gücker \& Pusch, 2006; Weigelhofer et al., 2013). In addition, excessive inputs of organic-rich soil may accumulate in small streams, thereby changing the sediment structure, restricting the hyporheic water exchange, and leading to oxygen depletion in the sediments (Hancock, 2002; Withers \& Jarvie, 2008; Teufl et al., 2013). Stream regulation and the removal of riparian forests increase the vulnerability of small streams to climate change-induced disturbances, such as increased water temperatures and water scarcity
(Kristensen \& Globevnik, 2014). Enhanced water temperatures and the repeated drying and re-wetting of stream sediments influence phosphorus uptake and release processes at the water-sediment interface (Reddy et al., 1999; Withers \& Jarvie, 2008). Besides, increased light penetration in combination with enhanced nutrient supply supports the growth of benthic algae and may change benthic processes from heterotrophy to autotrophy (Sabater et al., 2000; Niyogi et al., 2007; Burrows et al., 2013). Stream regulation also results in a homogenization of stream channels and an acceleration of water flow, thereby decreasing the physical retention function of headwater streams (Ensign \& Doyle, 2005; Weigelhofer et al., 2012). As a consequence, many headwater streams in intensively cultivated agricultural landscapes have lost their natural retention function for dissolved phosphorus and often act as mere transport systems to downstream reaches (Macrae et al., 2003; Dodds \& Oakes, 2008; McGarrigle, 2014).

The restoration of the retention function of such heavily impacted headwater streams represents a challenge for stream managers as the limited size and the high vulnerability of these water bodies restrict management options. Inadequate measures may even deteriorate the current situation, e.g., when flow obstructions promote siltation of phosphorus-rich soil particles which can act as a source of soluble reactive phosphorus (SRP) to the water column (Reddy et al., 1999; House, 2003). Restoration concepts for larger streams are, thus, often not transferable to small headwater streams. For a sustainable improvement of the phosphorus retention function of agricultural headwater streams it is, thus, essential to understand the key processes and influencing factors which determine in-stream phosphorus uptake and release within a phosphorus-enriched environment.

The current research focused on the capacity of small, agricultural headwater streams to retain SRP. In specific, I wanted to know how channel morphology and bank vegetation influence in-stream phosphorus uptake at high phosphorus loads. For that purpose, short-term SRP additions were performed in reaches differing in channel morphology and riparian vegetation. The study was based on the hypotheses that

(1) agricultural headwater streams will generally show a decreased efficiency for in-stream SRP uptake compared to oligotrophic headwater streams 
(2) among agricultural headwater streams, reaches with meandering channels will show a higher SRP uptake than channelized sections due to higher hydrologic retention and

(3) unshaded reaches will show a higher SRP uptake than shaded reaches due to higher benthic algal biomass in summer.

As sediments of agricultural streams may store high amounts of phosphorus (Teufl et al., 2013), the study focused on the role of sediments as sinks or sources for SRP and their influence on the in-stream SRP uptake. Based on adsorption experiments, the zero equilibrium phosphorus concentration of the sediments $\left(\mathrm{EPC}_{0}\right)$ was estimated (Reddy et al., 1999; House, 2003). The $\mathrm{EPC}_{0}$ is the SRP concentration in water above sediments where no net SRP sorption or desorption occurs (House, 2003; Stutter \& Lumsdon, 2008). Hence, sediments with lower $\mathrm{EPC}_{0}$ than stream water concentrations function as sinks, those with higher $\mathrm{EPC}_{0}$ as sources for SRP. I hypothesized that study reaches with low in-stream SRP uptake will show higher $\mathrm{EPC}_{0}$ values than study reaches with higher instream SRP uptake.

\section{Materials and methods}

Study area

Until the eighteenth century, the north-eastern part of Austria, known as the Weinviertel, was predominantly marshland with small, meandering, and usually unshaded streams (Weigelhofer et al., 2012, 2013). However, due to an intensification of agricultural land use, the former marshland was drained and most headwater streams were channelized. Nowadays, the Weinviertel is one of the most productive agricultural regions in Austria in which grain and wine are cultivated. The majority of headwater streams are heavily degraded, flowing through straightened and deeply incised channels. In most cases, crop fields extend to the upper margins of the homogenous banks which are covered by reed, grass, and other herbaceous plants (Weigelhofer et al., 2012, 2013).

In order to study the effects of channel morphology and bank vegetation on in-stream phosphorus uptake under similar nutrient background conditions, I tried to find streams which showed both channelized and non- channelized reaches. This was not always possible, considering the requirements for nutrient addition experiments such as e.g., minimum length of the reach without lateral surface or subsurface inflows, homogeneity of channel morphology and bank vegetation throughout the whole study reach (including shading), and accessibility. At last, fourteen study reaches within nine headwater streams were selected for the study (Fig. 1). Sites within the same stream were at least $1 \mathrm{~km}$ apart from each other and the sampling was always done from downstream to upstream to avoid interference between sampling sites. Each of the 200-m-long reaches was sampled once during low water level in summer 2009, 2010, and 2011, respectively, amounting to 42 data points in total. Prior to the investigations, the study reaches were assigned to three groups (Table 1). Group 1 (forested sections, 5 sites) consisted of meandering channels with either restored or pristine riparian forest buffers on both banks. The channels showed a heterogeneous steppool pattern and were shaded from April to November. Group 2 (open meanders, 4 sites) was characterized by meandering channels bordered by heterogeneous banks with herbaceous vegetation. As these sections were unshaded in summer, sporadic macrophytes or helophytes (e.g., Mentha aquatica, Ranunculus circinatus) were found on the channel bed. Group 3 (channelized sections, 5 sites) represented deforested, channelized reaches characterized by homogenous, steep, and V-shaped banks and straightened stream courses. Owing to channel incision, these sections were shaded from May to September when the herbaceous bank vegetation was tall enough to cover the entire channel width.

At all sites, sediments consisted mainly of organicrich clay and sand originating from eroded soil and became anoxic below $3-10 \mathrm{~cm}$ depth (Teufl et al., 2013).

\section{Short-term nutrient additions}

To quantify the in-stream uptake of SRP, we conducted three short-term additions of sodium dihydrogen phosphate $\left(\mathrm{Na}\left(\mathrm{H}_{2} \mathrm{PO}_{4}\right) \cdot 2 \mathrm{H}_{2} \mathrm{O}\right)$ and a conservative tracer (sodium chloride, $\mathrm{NaCl}$ ) at each study site between May and September 2009, 2010, and 2011, respectively, according to the protocol of the Stream Solute Workshop (1990). Details are given in Weigelhofer et al. (2012, 2013). In short, SRP and sodium 
Fig. 1 Site map, showing the location of the Weinviertel in the northeastern part of Austria, the study sites, and major rivers in Austria (Danube, Dyje, and Morava). Gray circle sites investigated for instream SRP uptake; black circle sites investigated for both SRP uptake and adsorption experiments

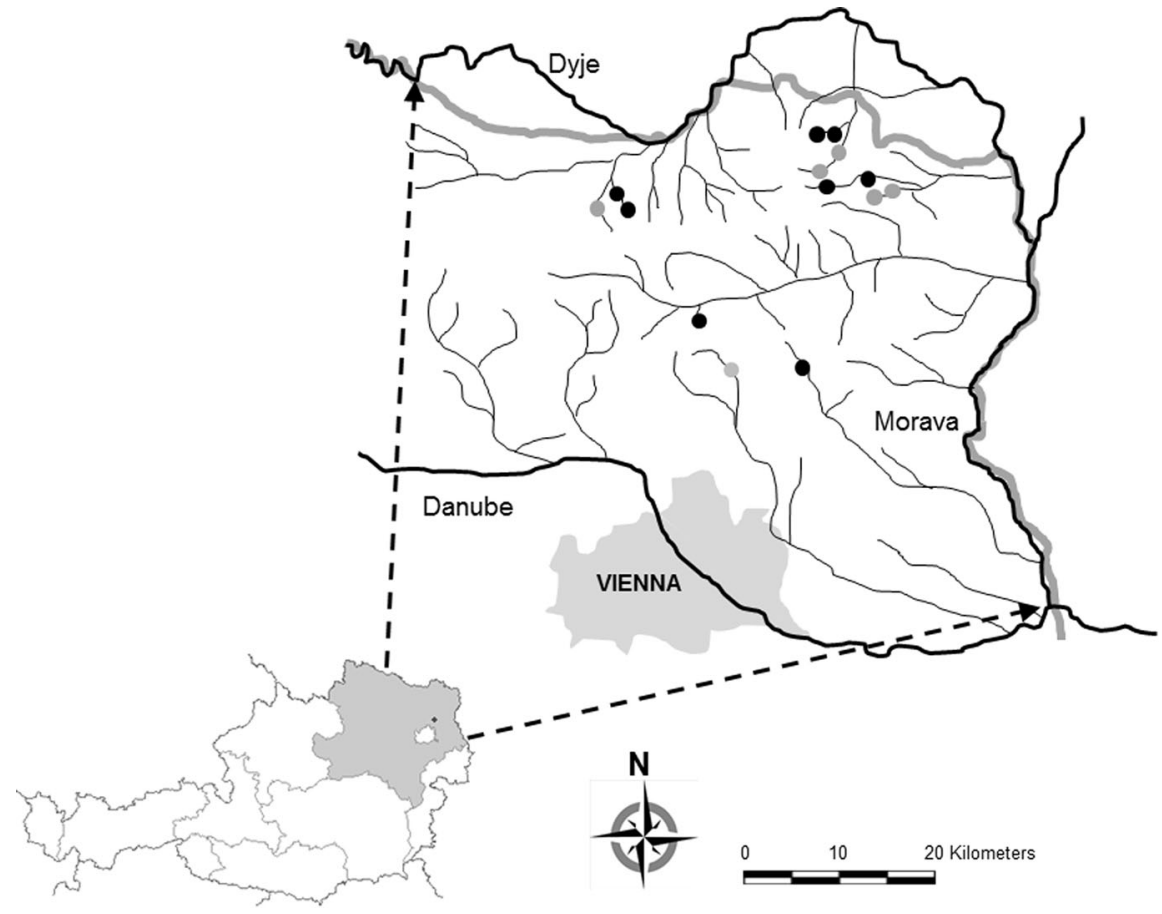

Table 1 Hydromorphological and chemical characteristics of the reach groups during the short-term phosphorus additions in summer 2009, 2010, and 2011, respectively (mean \pm standard deviation)

\begin{tabular}{|c|c|c|c|c|}
\hline Parameter & Unit & $\begin{array}{l}\text { Group } 1 \\
\text { Forested sections (A) }\end{array}$ & $\begin{array}{l}\text { Group } 2 \\
\text { Open meanders (B) }\end{array}$ & $\begin{array}{l}\text { Group } 3 \\
\text { Channelized } \\
\text { sections }(\mathrm{C})\end{array}$ \\
\hline Number of sites & & 5 & 4 & 5 \\
\hline Shading & & $100 \%$ & $10 \%$ & $100 \%$ \\
\hline In-stream vegetation & & $\begin{array}{l}\text { Predominantly } \\
\text { diatoms }\end{array}$ & $\begin{array}{l}\text { Filamentous green algae, } \\
\text { some macrophytes }\end{array}$ & $\begin{array}{l}\text { Predominantly } \\
\text { diatoms }\end{array}$ \\
\hline Discharge & $1 \mathrm{~s}^{-1}$ & $4.9 \pm 4.4$ & $4.4 \pm 2.7$ & $7.0 \pm 5.6$ \\
\hline Channel width & $\mathrm{m}$ & $0.07 \pm 0.03$ & $0.06 \pm 0.02$ & $0.08 \pm 0.03$ \\
\hline Water depth & $\mathrm{m}$ & $0.8 \pm 0.2$ & $0.7 \pm 0.2$ & $0.8 \pm 0.4$ \\
\hline Water velocity & $\mathrm{m} \mathrm{s}^{-1}$ & $0.07 \pm 0.04$ & $0.11 \pm 0.04$ & $0.11 \pm 0.05$ \\
\hline As/A & & $0.57 \pm 0.6$ & $0.18 \pm 0.1$ & $0.12 \pm 0.1$ \\
\hline Background DIN & $\mathrm{mg}^{-1}$ & $4.6 \pm 2.2$ & $4.4 \pm 2.8$ & $4.0 \pm 1.1$ \\
\hline Background SRP & $\mathrm{mg}^{-1}$ & $0.09 \pm 0.05^{\mathrm{C}}$ & $0.16 \pm 0.17^{\mathrm{C}}$ & $0.41 \pm 0.34^{\mathrm{A}, \mathrm{B}}$ \\
\hline Benthic Chl-a & $\mathrm{g} \mathrm{m}^{-2}$ & $0.2 \pm 0.1^{\mathrm{B}}$ & $1.2 \pm 0.9^{\mathrm{A}}$ & $0.9 \pm 1.7$ \\
\hline SRP uptake rate & $\mathrm{mg} \mathrm{m}^{-2} \min ^{-1}$ & $0.04 \pm 0.04$ & $0.11 \pm 0.15$ & $0.09 \pm 0.11$ \\
\hline
\end{tabular}

$A s / A$ relative extension of transient storage zone, DIN dissolved inorganic nitrogen; SRP soluble reactive phosphorus Superscripts (A, B, C) indicate significant differences between groups

chloride were injected at constant rate into each study reach for $2 \mathrm{~h}$ via a peristaltic pump to achieve an SRP increase three- to four-fold that of the background level. The sodium chloride was used to correct downstream nutrient changes for groundwater inflow, define complete solute mixing along the whole study 
reach (=plateau conditions), and estimate hydrological retention. For the latter two reasons, electrical conductivity was recorded with a Hach Lange HQ40d conductivity meter at the bottom of each reach at $10 \mathrm{~s}$ intervals from the start of the injection until background conditions were reached again after turning of the injection. Before the addition and after reaching plateau conditions, we took triplicate water samples at $40,80,120,160$, and $200 \mathrm{~m}$ downstream of the injection point (15 samples in total per site). Water samples were filtered with $0.45 \mu \mathrm{m}$ GFF filters in the field, transported to the laboratory in a dark cooler, and analyzed on the next day for SRP, $\mathrm{Cl}, \mathrm{N}-\mathrm{NH}_{4}, \mathrm{~N}-\mathrm{NO}_{3}$, and $\mathrm{N}-\mathrm{NO}_{2}$ concentrations using standard colorimetric methods (Eaton et al., 2005).

In-stream SRP uptake was expressed via the SRP uptake length (representing the mean travel distance of the SRP ion in the water column before it is taken up), the mass transfer coefficient (representing the mean SRP uptake velocity), and the SRP uptake rate (Weigelhofer et al., 2012, 2013). All three SRP uptake parameters were calculated from the longitudinal decline of SRP concentrations along the study reach during plateau conditions (Stream Solute Workshop, 1990; Bernot et al., 2006; Gücker \& Pusch, 2006). In order to correct for SRP decreases caused by dilution through groundwater inflow, SRP concentrations were divided by chloride concentrations. SRP uptake lengths, mass transfer coefficients, and uptake rates were calculated via first-order regression curves of the corrected SRP concentrations against distance from the injection point (Stream Solute Workshop, 1990).

Immediately after each experiment (i.e., after reaching background conductivity again), discharge and channel morphology were measured and sediment samples were taken for analyses of grain size distribution, nutrient and organic matter content, and benthic chlorophyll-a concentrations as described in Weigelhofer et al. (2013) and Teufl et al. (2013). Hydrologic retention was calculated from the conductivity break-through curves of the salt injections via the one-dimensional solute transport model OTIS-P according to Runkel (1998). Hydrologic retention was expressed as the relative extension of the transient storage zone (As) to the cross-sectional area (A) of the stream as As/A (Weigelhofer et al., 2013). The transient storage zone accounts for all regions of the stream which temporarily detain solutes relative to the free flowing water (Runkel, 1998).
Sedimentary SRP release or uptake

In summer 2013, uptake and release experiments were performed with samples of the undisturbed sediment surface. Due to severe changes in sediment structure at some study sites (e.g., after channel excavations and removal of bank vegetation for flood protection), only sediments of 8 sites could be studied, including three forested sections, three channelized sections, and two open meanders (Table 2). Sediment samples were cut out of the sediment surface with a small corer (depth $1 \mathrm{~cm}$, diameter $3 \mathrm{~cm}$ ) and transported carefully to the laboratory in a cooler without disrupting the sediment structure. There, sediments were exposed to $80 \mathrm{ml}$ SRP-enriched Milli-Q water in $100 \mathrm{ml}$ plastic jars and the change in SRP concentrations in the water column was recorded after $8,16,24,36$, and $48 \mathrm{~h}$ incubation under gentle shaking at $20^{\circ} \mathrm{C}$ in the dark $(n=5$ per treatment and stream, respectively). The initial SRP concentrations in the water were $0 \mu \mathrm{g}^{-1}$ (Milli-Q water), $250 \mu \mathrm{g} \mathrm{l}^{-1}$, and $500 \mu \mathrm{g} \mathrm{SRP}{ }^{-1}$. The jars were covered with aluminum foil to facilitate oxygen exchange between the air and the headspace in the jar. On average, oxygen concentrations in the water column ranged from 5 to $7 \mathrm{mg} 1^{-1}$ during the experiments. Based on the incubations with Milli-Q water, SRP release rates were calculated from the increase in SRP concentrations over the first $8 \mathrm{~h}$ divided by the area of the sampled sediment surface and the incubation time $\left(\mathrm{mg} \mathrm{P} \mathrm{m}^{-2} \mathrm{~h}^{-1}\right)$.

In summer 2014 and 2015, additional adsorption experiments were performed to estimate the $\mathrm{EPC}_{0}$ of the selected sites (Reddy et al., 1999; House, 2003). For the experiments, $10 \mathrm{~g}$ homogenized wet sediments from the upper sediment layer were exposed to $60 \mathrm{ml}$ Milli-Q water enriched with different SRP concentrations $\left(0,13,55,120,247\right.$, and $\left.555 \mu \mathrm{g} \mathrm{SRP} 1^{-1}\right)$ under continuous shaking over $24 \mathrm{~h}$ in the dark. Amounts of adsorbed or desorbed SRP per gram sediment were calculated via the difference between the initial and the final SRP concentrations in the water divided by the sediment dry weight (Stutter \& Lumsdon, 2008). $\mathrm{EPC}_{0}$ values were estimated as the $\mathrm{X}$-intercept of linear regression curves by plotting the amount of adsorbed or desorbed SRP against the SRP concentrations of the water after $24 \mathrm{~h}$ (Reddy et al., 1999).

Sediment subsamples ( $n=5$ per reach) were analyzed for initial phosphorus concentrations via parallel extractions with $1 \mathrm{M} \mathrm{NH}_{4} \mathrm{Cl}$ (soluble $\mathrm{P}$ ), $0.11 \mathrm{M}$ 
Table 2 Phosphorus concentrations and release rates of the investigated sediments (mean $\pm \operatorname{SD} ; n=5$ )

\begin{tabular}{|c|c|c|c|c|c|c|}
\hline Sites $^{\mathrm{a}}$ & Group & $\begin{array}{l}\text { Ptot } \\
\left(\mathrm{mg} \mathrm{kg}^{-1}\right)\end{array}$ & $\begin{array}{l}\text { Soluble P } \\
\left(\mathrm{mg} \mathrm{kg}^{-1}\right)\end{array}$ & $\begin{array}{l}\text { Reductant-soluble P } \\
\left(\mathrm{mg} \mathrm{kg}^{-1}\right)\end{array}$ & $\begin{array}{l}\text { Pinorg } \\
\left(\mathrm{mg} \mathrm{kg}^{-1}\right)\end{array}$ & $\begin{array}{l}\text { P release rates } \\
\left(\mathrm{mg} \mathrm{m}^{-2} \mathrm{~h}^{-1}\right)\end{array}$ \\
\hline $\mathrm{Hi}$ & 1 & $1,121 \pm 152$ & $7.1 \pm 0.9$ & $156 \pm 16$ & $820 \pm 282$ & 0.9 \\
\hline Str1 & 1 & $1,085 \pm 257$ & $8.0 \pm 0.2$ & $186 \pm 8$ & $1,048 \pm 419$ & 1.0 \\
\hline Str2 & 3 & $1,265 \pm 114$ & $9.7 \pm 1.0$ & $305 \pm 23$ & $920 \pm 15$ & 1.5 \\
\hline Stu1 & 1 & $1,078 \pm 131$ & $3.5 \pm 1.0$ & $101 \pm 10$ & $591 \pm 87$ & 0.4 \\
\hline Stu2 & 2 & $721 \pm 160$ & $1.8 \pm 0.6$ & $95 \pm 7$ & $400 \pm 117$ & 0.3 \\
\hline He1 & 2 & $1,204 \pm 369$ & $4.5 \pm 0.5$ & $181 \pm 10$ & $453 \pm 51$ & 0.6 \\
\hline $\mathrm{He} 2$ & 3 & $917 \pm 105$ & $1.7 \pm 0.2$ & $92 \pm 12$ & $424 \pm 7$ & 0.5 \\
\hline Wei & 3 & $1,100 \pm 255$ & $1.7 \pm 0.5$ & $344 \pm 45$ & $670 \pm 120$ & 1.6 \\
\hline
\end{tabular}

Ptot total phosphorus; Pinorg inorganic phosphorus

${ }^{\text {a }}$ Hipples stream; Stronsdorf stream; Stutzenhofen stream; Herrnbaumgarten stream; Weiden stream

bicarbonate-dithionite (reductant-soluble $\mathrm{P}$ ), and $1 \mathrm{M}$ $\mathrm{HCl}$ (inorganic P) modified after Psenner et al. (1988) and Ruban et al. (2001). Total phosphorus concentrations $\left(\mathrm{P}_{\text {tot }}\right)$ were measured after acid digestion of the sediments in a microwave oven (CEM MarsXpress) according to EPA method 3051 (US-EPA, 2014).

\section{Statistics}

Linear regression analyses were used to test whether the slopes of the SRP regression curves were statistically significant from zero. Significant slopes indicate SRP uptake in the respective reach, while insignificant slopes indicate no SRP uptake.

Data were first tested for normality and homogeneity of variance with Kolmogorov-Smirnov and Levene tests. Kruskal-Wallis and Mann-Whitney U tests were applied to check for significant differences in hydromorphology, SRP concentrations, SRP uptake parameters, and chlorophyll-a concentrations among groups. Correlations among hydromorphology, water quality, and SRP uptake parameters as well as between $\mathrm{EPC}_{0}$ values and sediment parameters were identified by Spearman's correlation tests. All statistical analyses were performed using SPSS 15.0 for Windows (SPSS Inc., Chicago, USA, 2006).

\section{Results}

In-stream SRP uptake

Groups differed significantly in SRP background concentrations (Kruskal-Wallis, $\chi^{2}=8.7, P<0.02$, $d f=2$ ) and chlorophyll-a concentrations (KruskalWallis, $\chi^{2}=7.5, P<0.03, d f=2$ ). Channelized sections showed significantly higher average SRP concentrations than forested sections $(U$ test, $P<0.006, n=30$ ) and open meanders ( $U$ test, $P<0.03, n=27$; Table 1; Fig. 2). Benthic chlorophyll-a concentrations were highest in open meanders, followed by channelized and forested sections. Differences were significant between open meanders and forested sections ( $U$ test, $P<0.01, n=27$ ). Groups showed similar discharges, channel widths, and water depths, while mean water velocity was slightly, though not significantly, lower and hydrologic retention (As/A) slightly higher in forested sections than in the other groups (Kruskal-Wallis, $P>0.05$ ).

In some cases, SRP uptake regression curves yielded slopes which were not significantly different from zero, indicating no SRP uptake over the respective reach (Online Resource 1). In order not to lose this information, uptake parameters from insignificant regression curves were kept in the analyses, but marked separately in the graphs (Fig. 2a, b). Groups differed significantly in SRP uptake lengths (KruskalWallis, $\left.\chi^{2}=13.2, \quad P<0.002, d f=2\right)$ and mass transfer coefficients (Kruskal-Wallis, $\chi^{2}=10.0$, $P<0.007, d f=2)$. Average SRP uptake lengths were significantly longer in channelized sections $(3.8 \mathrm{~km})$ than in forested sections $(1.9 \mathrm{~km} ; U$ test, $P<0.06, n=42)$ and open meanders $(0.5 \mathrm{~km} ; U$ test, $P<0.03, n=42$; Fig. 2a). About $50 \%$ of the addition experiments in channelized sections yielded insignificant regression curves (Online Resource 1). In addition, two of the forested sections showed insignificant SRP uptake on three occasions. Mass transfer 

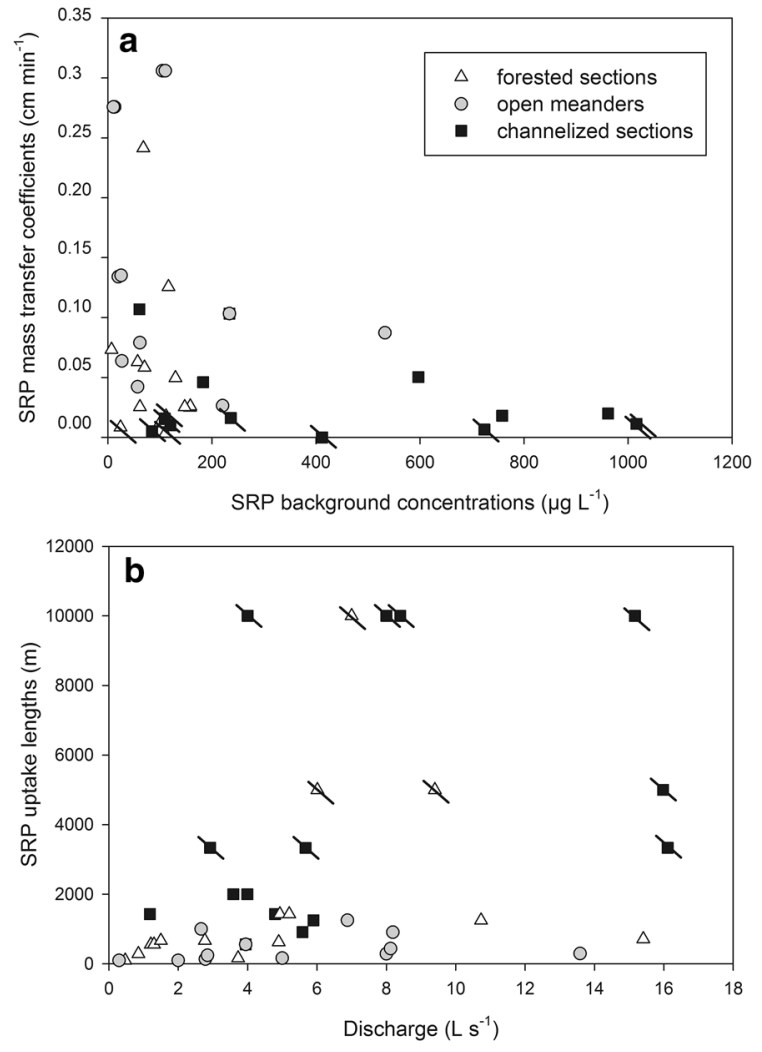

Fig. 2 In-stream SRP uptake parameters derived from SRP short-term addition experiments in agricultural headwater streams in the Weinviertel $(n=42$ in total). a SRP mass transfer coefficients versus SRP background concentrations during the experiments. b SRP uptake lengths versus discharge during the experiments. Uptake parameters calculated from insignificant regression curves are crossed out

coefficients were significantly higher in open meanders $\left(0.1 \mathrm{~cm} \mathrm{~min}^{-1}\right)$ than in forested reaches $\left(0.05 \mathrm{~cm} \mathrm{~min}^{-1} ; U\right.$ test, $\left.P<0.02, n=42\right)$ and channelized sections $\left(0.04 \mathrm{~cm} \mathrm{~min}^{-1} ; U\right.$ test, $P<0.006$, $n=42$; Fig. 2 b). Average SRP uptake rates ranged from 0.04 to $0.1 \mathrm{mg} \mathrm{m}^{-2} \mathrm{~min}^{-1}$ and did not differ significantly among groups (Table 1).

SRP background concentrations showed the largest influence on SRP uptake parameters, yielding significant correlations with mass transfer coefficients (Spearman correlation coefficients $-0.35, P<0.04$, $n=42$ ), uptake lengths (correlation coefficients 0.35 , $P<0.04, n=42$ ), and uptake rates (correlation coefficients $0.41, P<0.02, n=42$ ). In addition, SRP uptake lengths correlated positively with discharge (correlation coefficient 0.39, $P<0.02$, $n=42$ ). SRP uptake parameters did not correlate with any of the other hydromorphological, biological, or chemical parameters.

Sedimentary SRP release or uptake

Sedimentary SRP uptake and release did not reveal any consistent pattern among the hydromorphological groups (Fig. 3). However, different morphological reaches within the same stream often showed similar release or uptake characteristics. In the incubation with Milli-Q water, SRP was released from all sediments, but release curves differed markedly among the different sites. Lowest SRP concentrations after $48 \mathrm{~h}$ were observed in the sediments of both sites of Stutzenhofen stream (one forested section, one open meander) and Herrnbaumgarten stream (one open meander, one channelized section) with $20-50 \mu \mathrm{g}$ SRP $1^{-1}$ (Fig. 3), yielding SRP release rates of 0.3-0.6 mg P m ${ }^{-2} \mathrm{~h}^{-1}$ (Table 2). Equilibrium conditions between water and sediments were already reached after $8 \mathrm{~h}$. In contrast, the two channelized sections in Stronsdorf stream and Weiden stream (Str2 and Wei) showed a continuous sedimentary SRP release over the entire experiment, reaching SRP concentrations of $>1,000 \mu \mathrm{g}^{-1}$ after $48 \mathrm{~h}$ (Fig. 3). SRP release rates amounted to $1.5-1.6 \mathrm{mg} \mathrm{P} \mathrm{m}^{-2} \mathrm{~h}^{-1}$ at these sites (Table 2). The forested section Str1 of Stronsdorf stream yielded distinctly lower SRP release rates than the channelized section Str2 (Table 2). However, final SRP concentrations in the water above the sediments of Str1 were 2-4 times higher than those of the other forested sections Stu1 and Hi (Fig. 3). In the incubations with 250 and $500 \mu \mathrm{g} \mathrm{SRP} 1^{-1}$, the two channelized sections Str2 and Wei showed again a continuous SRP release over the entire incubation period. SRP concentrations remained more or less stable in the experiments with sediments from the forested site Str1, indicating no net SRP uptake or release there, while all other sites showed sedimentary SRP uptake from the water column (indicated by decreasing SRP concentrations in the water during the incubation).

The adsorption experiments largely reflected the results of the release and uptake experiments. The lowest $\mathrm{EPC}_{0}$ values were observed in the sediments of Stutzenhofen stream (Stu1, Stu2) and Herrnbaumgarten stream ( $\mathrm{He} 1, \mathrm{He} 2)$, ranging from 20 to $60 \mu \mathrm{g}$ SRP $1^{-1}$ (Fig. 4). $\mathrm{EPC}_{0}$ of Stu1 and Stu2 almost equaled average background SRP concentrations in 
Fig. 3 Changes in SRP concentrations in the water column above the sediments of selected reaches during incubation under different initial SRP concentrations (means, $n=5$ ). Increasing SRP concentrations indicate sedimentary SRP release, decreasing concentrations indicate sedimentary SRP uptake. Strl forested site at Stronsdorf stream; Str2 channelized site at Stronsdorf stream; Wei channelized site at Weiden stream
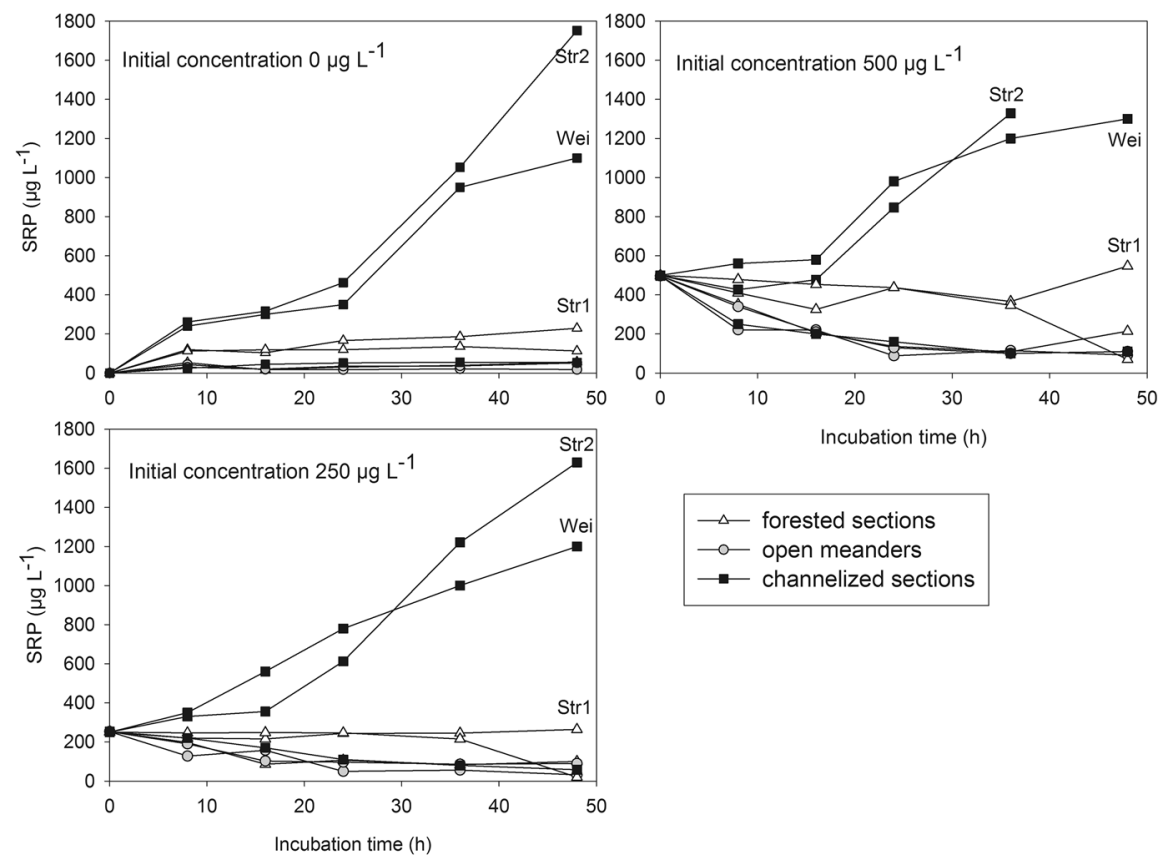

$\_\_$forested sections $\multimap$ open meanders $\longrightarrow$ - channelized sections this stream, indicating that stream water and sediments were balanced at these sites. In Herrnbaumgarten stream, $\mathrm{EPC}_{0}$ values were about $1 / 10$ of the average SRP background concentrations, showing a high potential of the stream sediments to act as $\mathrm{P}$ sinks there. $\mathrm{EPC}_{0}$ were highest in the two channelized sections Str2 and Wei (1,500-1,600 $\mu \mathrm{g}$ SRP $1^{-1}$, Fig. 4) and exceeded stream water SRP concentrations by far, indicating that the sediments may act as $\mathrm{P}$

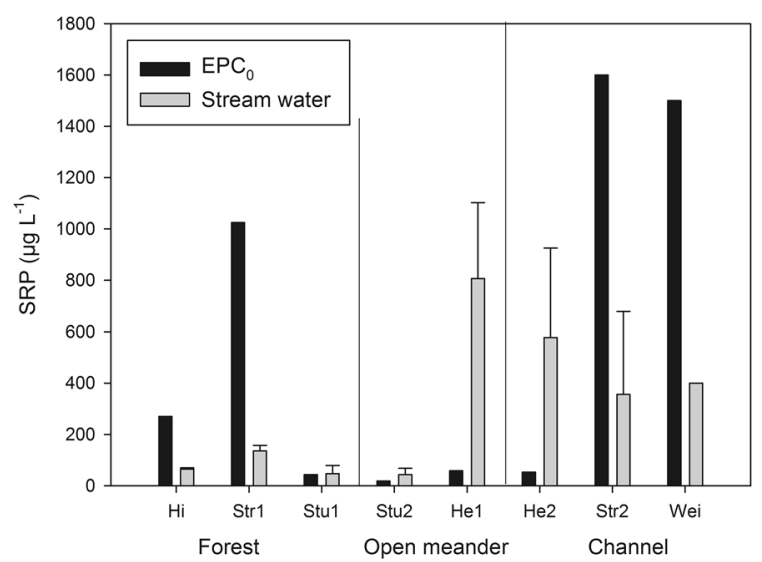

Fig. 4 Equilibrium phosphorus concentrations $\left(\mathrm{EPC}_{0}\right)$ and average background SRP concentrations of selected reaches (Hi Hipples stream; Str Stronsdorf stream; Stu Stutzenhofen stream; He Herrnbaumgarten stream; Wei Weiden stream). For the average background SRP concentrations, means and standard deviations are shown $(n=3-5)$ sources at these sites. The forested section Str1 of Stronsdorf stream also showed highly elevated $\mathrm{EPC}_{0}$ of $>1,000 \mu \mathrm{g} \mathrm{SRP} \mathrm{l}^{-1}$.

$\mathrm{EPC}_{0}$ correlated positively with the concentrations of inorganic P (Spearman correlation coefficient 0.7, $P<0.05, n=8)$ and reductant-soluble $\mathrm{P}$ in the sediments (correlation coefficient $0.9, P<0.004$, $n=8$ ). However, $\mathrm{EPC}_{0}$ correlated neither with background SRP concentrations nor with any of the uptake parameters of the selected streams $(P>0.05)$.

\section{Discussion}

As hypothesized, in-stream SRP uptake was generally much lower in the agricultural streams of the Weinviertel than in other headwater streams of similar size. SRP uptake lengths in oligotrophic headwater streams usually range from less than $100 \mathrm{~m}$ (e.g., Webster et al., 1991; Hall et al., 2002; Schade et al., 2010; Gibson et al., 2015) to a few $100 \mathrm{~m}$ (e.g., Burrows et al., 2013). In contrast, most studies in agricultural headwater streams report extremely low SRP uptake capacities, often featuring uptake lengths of several kilometers (e.g., Macrae et al., 2003; Bernot et al., 2006; Gücker \& Pusch, 2006). Sheibley et al. (2014) did not measure any in-stream SRP uptake at all, as was also the case in some of the Weinviertel streams. 
In their review about 969 nutrient uptake experiments, Hall et al. (2013) observed that SRP uptake lengths were generally longer in human-impacted streams than in pristine systems.

In the current study, the shortest SRP uptake lengths amounted to $95 \mathrm{~m}$ and were measured once in an open meander and once in a forested section, respectively. Uptake lengths below $300 \mathrm{~m}$, which are comparable to those of pristine streams, were found on 3 sampling dates in open meanders and forested sections, respectively, and once in a channelized section. Thus, agricultural headwater streams have the potential to effectively retain SRP even though the overall nutrient loading of the catchment may be high. Phosphorus retention in agricultural headwater streams is not simply a function of SRP loading from the terrestrial surroundings, but subject to the complex interaction among hydrological retention, microbial and algal uptake, and abiotic transformations at the watersediment interface, such as adsorption or desorption, and precipitation or dissolution (House, 2003; Withers \& Jarvie, 2008). One major factor determining SRP uptake in small headwater streams, at least during the vegetation period, is the riparian vegetation as it controls the activity of autotrophs via shading (Withers \& Jarvie, 2008). In our study, unshaded reaches showed significantly higher chlorophyll-a concentrations and SRP uptake than shaded reaches. Similar observations have been made by Bernot et al. (2006), Burrows et al. (2013), and McMillan et al. (2014). Sabater et al. (2000) found an increase in the biomass of benthic algae together with increased SRP uptake after riparian vegetation removal, emphasizing the role of riparian forests on in-stream processes in small streams. The influence of channel heterogeneity and hydrologic retention on SRP uptake in small streams is less obvious. In general, channelized sections showed lower SRP uptake capacities than the other reaches in the Weinviertel. However, forested sections, which displayed the highest hydrologic retention and the smallest mean water velocities of all reaches, featured only intermediate SRP uptake. SRP uptake studies from other regions show a likewise diverse picture. While in some studies, hydrologic retention played a major role in the SRP uptake (e.g., Ensign \& Doyle, 2005; Bukaveckas, 2007), Hall et al. (2002) and Niyogi et al. (2004) found no correlation between SRP uptake and transient storage in their study streams. Hydrologic retention in sandy-bottomed streams with restricted hyporheic water exchange is mainly due to surface transient storage (Ensign \& Doyle, 2005; Bukaveckas, 2007; Weigelhofer et al., 2012). In small streams, even slight irregularities on the channel bed may lead to increased channel heterogeneity and surface transient storage during low water level. Thus, effects of channelization on the SRP uptake in such streams may be of minor importance during low water levels.

Low SRP uptake in agricultural streams can be attributed to several factors: the saturation of the benthic community (e.g., Bernot et al., 2006; Gücker \& Pusch, 2006), a reduced hydrologic retention of the channel (e.g., Sheibley et al., 2014), a restricted hyporheic water exchange with the sediments (Macrae et al., 2003), and reduced adsorption capacities of the sediments due to overloading (Stutter \& Lumsdon, 2008). In agricultural headwater streams, soil erosion and inefficient sediment transport may result in huge accumulations of reactive fine particles from the terrestrial surroundings on the channel bed. Clay and sand particles have a high potential to adsorb and desorb phosphorus and, thus, play a crucial role in the uptake, intermediate storage, and release of phosphorus to the water column (Meyer, 1979; Hall et al., 2002; Lottig \& Stanley, 2007; Schade et al., 2010). Especially in small streams, where benthic processes dominate over water column processes, phosphorus stored in sediments may influence the water chemistry significantly (Withers \& Jarvie, 2008). Various studies about equilibrium phosphorus concentrations have found a close coupling between sediment buffering capacities and SRP stream water concentrations (Meyer, 1979; Lottig \& Stanley, 2007; Stutter \& Lumsdon, 2008; McDaniel et al., 2009; McDowell, 2015). However, this was not the case in the current study, at least with respect to the selected reaches. A weak interaction between equilibrium phosphorus concentrations and water column SRP may be attributed, among others, to the chemical decoupling of sediments and water column due to recent perturbations of the sediments (e.g., after storm events) or fluctuations in water chemistry (Stutter \& Lumsdon, 2008). Especially in agricultural headwater streams, such an uncoupling of water and sediment chemistry may readily emerge. Small eutrophic streams can be subject to considerable changes in water quality during the day resulting from fluctuations in local inputs, diurnal patterns in the activity of the algal and microbial community, and discharge fluctuations 
caused by e.g., changes in evapotranspiration. In contrast, the sediments of agricultural streams are often tightly packed due to their fine texture (Hancock, 2002) and, thus, chemically relatively stable. During low discharge, the restricted hyporheic water exchange facilitates the development of steep chemical gradients in the upper sediment layers, thereby gradually filling up the phosphorus adsorption capacity of the particles (McDaniel et al., 2009; Weigelhofer et al., 2013). Consequently, sediments may act as phosphorus source during prolonged periods of low flow. In contrast, the mobilization of sediments during floods and the sedimentation of newly imported soil particles may rehabilitate the phosphorus adsorption capacity and lead to a temporary phosphorus uptake by sediments (McDaniel et al., 2009; McDowell, 2015).

In general, sediments are assumed to be a phosphorus sink at high SRP concentrations in the water and a phosphorus source at low concentrations (Stutter \& Lumsdon, 2008; McDaniel et al., 2009). However, the definition of "low" and "high" depends on the respective input situation, as the current study shows. In $25 \%$ of the investigated reaches, phosphorus was released from the sediments even at initial water column concentrations of $500 \mu \mathrm{g} \mathrm{SRP} 1^{-1}$, indicating a high release potential of stream sediments in the Weinviertel. While this potential may have been overestimated under oxic conditions due to the use of Milli-Q water in the experiments (McDaniel et al., 2009), the actual release potential may be even higher as most headwater streams in the Weinviertel show extended anoxic zones in the sediments below the first centimeters. Under anoxic conditions, huge amounts of reductive soluble phosphorus can be released from the sediments to the water column (House, 2003). Hence, benthic algae and microorganisms as well as adsorption sites of surface particles are continuously supplied with phosphorus from the subsurface. Although the study did not show a direct correlation between phosphorus equilibrium concentrations and in-stream SRP uptake, this continuous phosphorus supply from the sediments is probably one major reason for the reduced phosphorus uptake in the Weinviertel streams.

\section{Conclusion}

The study highlights the key role of sediments for the functioning of small streams. The nutrient retention capacity and the water quality of small streams are largely determined by the balance among the various processes at the water-sediment interface. In agricultural catchments, huge inputs of reactive fine soil particles from the surroundings may disrupt this natural balance and severely impair the retention capacity of these streams. As the ecological state of downstream reaches depend on an intact functioning of headwater streams, the rehabilitation of the retention function is crucial for the maintenance of a multitude of ecosystem services delivered by river ecosystems which are based on a good water quality (e.g., biodiversity, drinking water supply, recreation). Sustainable protection and restoration schemes must, thus, primarily concentrate on protecting small agricultural headwater streams from soil inputs. Apart from reducing soil erosion in the terrestrial surroundings via best-management practices, riparian buffer strips can effectively protect streams if they stretch over the entire stream length or, at least, are placed in strategic points of the catchment such as e.g., in preferential flow paths. In addition, the stabilization of the water regime through the reduction of drainage and the improvement of the hydrological retention in the catchment can buffer climate change effects and reduce favorable conditions for phosphorus release from sediments.

The current study emphasizes also the significance of including sediment conditions and sediment-water interactions in the assessment of the ecological status of stream ecosystems. Especially in small streams, water column concentrations may not reflect the actual state of nutrient enrichment. Phosphorus concentrations of the sediments and $\mathrm{EPC}_{0}$ can be used as indicators for long-term phosphorus enrichment of streams due to agricultural land use as well as for the potential of stream sediments to function as phosphorus sources to the water column. In the face of a changing climate, where water scarcity may pronounce water-sediment interactions, this information may be crucial for a sustainable management of river systems.

Acknowledgments Open access funding provided by University of Natural Resources and Life Sciences Vienna (BOKU). This study was funded by the Austrian Ministry of Science, Research, and Economy via the program "Sparkling Science" and by the European Regional Development Fund (European-Territorial-Cooperation Austria-Czech Republic 2007-2013), the Government of Lower Austria, and the Austrian Ministry of Environment. I thank Rosalie Lorenz, Jennifer Fuchsberger, and Birgit Grünsteidl for their support in the 
field and the laboratory work and Beate Pitzl for the nutrient analyses (WasserCluster Lunz).

\section{Compliance with ethical standards}

Conflict of interest The author declares that she has no conflict of interest.

Open Access This article is distributed under the terms of the Creative Commons Attribution 4.0 International License (http:// creativecommons.org/licenses/by/4.0/), which permits unrestricted use, distribution, and reproduction in any medium, provided you give appropriate credit to the original author(s) and the source, provide a link to the Creative Commons license, and indicate if changes were made.

\section{References}

Alexander, R. B., E. W. Boyer, R. A. Smith, G. E. Schwarz \& R. B. Moore, 2007. The role of headwater streams in downstream water quality. Journal of the American Water Resources Association 43: 41-59.

Eaton, A. D., L. S. Clesceri, E. W. Rice \& A. E. Greenberg, 2005. Standard Methods for the Examination of Water \& Wastewater, 21st ed. American Public Health Association, American Water Works Association, \& Water Environment Federation, Washington, DC.

Bernot, M. J., J. L. Tank, T. V. Royer \& M. B. David, 2006. Nutrient uptake in streams draining agricultural catchments of the midwestern United States. Freshwater Biology 51: 499-509.

Bouraoui, F. \& B. Grizzetti, 2011. Long term change of nutrient concentrations of rivers discharging in European seas. Science of the Total Environment 409: 4899-4916.

Bukaveckas, P. A., 2007. Effects of channel restoration on water velocity, transient storage, and nutrient uptake in a channelized stream. Environmental Science \& Technology 41: 1570-1576.

Burrows, R. M., J. B. Fellman, R. H. Magierowski \& L. A. Barmuta, 2013. Greater phosphorus uptake in forested headwater streams modified by clearfell forestry. Hydrobiologia 703: 1-14.

Dodds, W. K. \& R. M. Oakes, 2008. Headwater influences on downstream water quality. Environmental Management 41: $367-377$.

Elsaholi, O. S., E. Hannigan \& M. Kelly-Quinn, 2011. Nutrient and light limitation of algal biomass in selected streams in Ireland. Inland Waters 1: 74-80.

Ensign, S. H. \& M. W. Doyle, 2005. In-channel transient storage and associated nutrient retention: evidence from experimental manipulations. Limnology and Oceanography 50: 1740-1751.

Gibson, C. A., C. M. O’Reilly, A. L. Conine \& S. M. Lipshutz, 2015. Nutrient uptake dynamics across a gradient of nutrient concentrations and ratios at the landscape scale. Journal of Geophysical Research: Biogeoscience 120: 326-340.
Gordon, L. J., G. D. Peterson \& E. M. Bennett, 2008. Agricultural modifications of hydrological flows create ecological surprises. Trends in Ecology and Evolution 23: 211-219.

Gücker, B. \& M. T. Pusch, 2006. Regulation of nutrient uptake in eutrophic lowland streams. Limnology and Oceanography 51: 1443-1453.

Hall Jr, R. O., E. S. Bernhardt \& G. E. Likens, 2002. Relating nutrient uptake with transient storage in forested mountain streams. Limnology and Oceanography 47: 255-265.

Hall Jr, R. O., M. A. Baker, E. J. Rosi-Marshall, J. L. Tank \& J. D. Newbold, 2013. Solute-specific scaling of inorganic nitrogen and phosphorus uptake in streams. Biogeosciences 10: 7323-7331.

Hancock, P. J., 2002. Human impacts on the stream-groundwater exchange zone. Environmental Management 29: 763-781.

House, W. A., 2003. Geochemical cycling of phosphorus in rivers. Applied Geochemistry 18: 739-748.

Kavanagh, J. A. \& S. S. C. Harrison, 2014. The contribution of a drainage network to the spatial and temporal patterns of macroinvertebrate diversity across an agricultural headwater catchment. Biology and Environment: Proceedings of the Royal Irish Academy 114B: 181-197.

Kristensen, P. \& L. Globevnik, 2014. European small water bodies. Biology and Environment: Proceedings of the Royal Irish Academy 114B: 281-287.

Lottig, N. R. \& E. H. Stanley, 2007. Benthic sediment influence on dissolved phosphorus concentrations in a headwater stream. Biogeochemistry 84: 297-309.

Macrae, M. L., M. C. English, S. L. Schiff \& M. A. Stone, 2003. Phosphate retention in an agricultural stream using experimental additions of phosphate. Hydrological Processes 17: 3649-3663.

McDaniel, M. D., M. B. David \& T. V. Royer, 2009. Relationships between benthic sediments and water column phosphorus in Illinois streams. Journal of Environmental Quality 38: 607-617.

McDowell, R. W., 2015. Relationship between sediment chemistry, equilibrium phosphorus concentrations, and phosphorus concentrations at baseflow in rivers of the New Zealand National River Water Quality Network. Journal of Environmental Quality 44: 921-929.

McGarrigle, M., 2014. Assessment of small water bodies in Ireland. Biology and Environment: Proceedings of the Royal Irish Academy 114B: 119-128.

McMillan, S. K., A. K. Tuttle, G. D. Jennings \& A. Gardner, 2014. Influence of restoration age and riparian vegetation on reach-scale nutrient retention in restored urban streams. Journal of the American Water Resources Association 50: 626-638.

Merseburger, G. C., E. Marti \& F. Sabater, 2005. Net changes in nutrient concentrations below a point source input in two streams draining catchments with contrasting land uses. Science of the Total Environment 347: 217-229.

Meyer, J. L., 1979. The role of sediments and bryophytes in phosphorus dynamics in a headwater stream ecosystem. Limnology and Oceanography 24: 365-375.

Niyogi, D. K., K. S. Simon \& C. R. Townsend, 2004. Land use and stream ecosystem functioning: nutrient uptake in streams that contrast in agricultural development. Archiv für Hydrobiologie 160: 471-486. 
Oenema, O., L. van Liere \& O. Schoumans, 2005. Effects of lowering nitrogen and phosphorus surpluses in agriculture on the quality of groundwater and surface water in the Netherlands. Journal of Hydrology 304: 289-301.

Psenner, R., B. Bostrom, M. Dinka, K. Petterson, R. Pucsko \& M. Sager, 1988. Fractionation of phosphorus in suspended matter and sediment. Archiv für Hydrobiologie Beiheft 30: 98-110.

Reddy, K. R., R. H. Kadlec, E. Flaig \& P. M. Gale, 1999. Phosphorus retention in streams and wetlands: a review. Critical Reviews in Environmental Science and Technology 29: 83-146.

Ruban, V., J. F. López-Sánchez, P. Pardo, G. Rauret, H. Muntau \& P. Quevauviller, 2001. Harmonized protocol and certified reference material for the determination of extractable contents of phosphorus in freshwater sediments - a synthesis of recent works. Fresenius Journal of Analytical and Bioanalytical Chemistry 370: 224-228.

Runkel, R. L., 1998. One Dimensional Transport with Inflow and Storage (OTIS): A Solute Transport Model for Streams and Rivers. U.S. Geological Survey Water-Resources Investigation Report 98-4018.

Sabater, F., A. Butturini, E. Marti, I. Munnoz, A. Romani, J. Wray \& S. Sabater, 2000. Effects of riparian vegetation removal on nutrient retention in a Mediterranean stream. Journal of the North American Benthological Society 19: 609-620.

Schade, J. D., K. MacNeill, S. A. Thomas, F. C. McNeely, J. R. Welter, J. Hood, M. Goodrich, M. E. Power \& J. C. Finlay, 2010. The stoichiometry of nitrogen and phosphorus spiraling in heterotrophic and autotrophic streams. Freshwater Biology 56: 424-436.

Sheibley, R. W., J. H. Duff \& A. J. Tesoriero, 2014. Low transient storage and uptake efficiencies in seven agricultural streams: implications for nutrient demand. Journal of Environmental Quality 43: 1980-1990.
Stream Solute Workshop, 1990. Concepts and methods for assessing solute dynamics in stream ecosystems. Journal of the North American Benthological Society 9: 95-119.

Stutter, M. I. \& D. G. Lumsdon, 2008. Interactions of land use and dynamic river conditions on sorption equilibria between benthic sediments and river soluble reactive phosphorus concentrations. Water Research 42: 4249-4260.

Tank, J. L. \& W. K. Dodds, 2003. Nutrient limitation of epilithic and epixylic biofilms in ten North American streams. Freshwater Biology 48: 1031-1049.

Teufl, B., G. Weigelhofer, J. Fuchsberger \& T. Hein, 2013. Effects of bank and channel morphology on the sediment quality of agricultural low-order streams. Environmental Science and Pollution Research 20: 1781-1793.

US-EPA, 2014. SW-846: Test Methods for Evaluating Solid Waste, Physical/Chemical Methods, 3rd ed. National Technical Information Service, US Department of Commerce, Alexandria, USA. http://www3.epa.gov/epawaste/ hazard/testmethods/sw846/online/.

Webster, J. R., D. J. D’Angelo \& G. T. Peters, 1991. Nitrate and phosphate uptake at Coweeta Hydrologic Laboratory. Verhandlungen der Internationalen Vereinigung für Limnologie 24: 1681-1686.

Weigelhofer, G., J. Fuchsberger, B. Teufl, N. Welti \& T. Hein, 2012. Effects of riparian forest buffers on in-stream nutrient retention in agricultural catchments. Journal of Environmental Quality 41: 373-379.

Weigelhofer, G., N. Welti \& T. Hein, 2013. Limitations of stream restoration for nitrogen retention in agricultural headwater streams. Ecological Engineering 60: 224-234.

Withers, P. J. A. \& H. P. Jarvie, 2008. Delivery and cycling of phosphorus in rivers: a review. Science of the Total Environment 400: 379-395. 